\title{
Implementation of Model Student Team's Achievement Divisions to Student Achievement
}

\author{
Minzani Aufa ${ }^{1 *}$, Akhmad Liana Amrul Haq ${ }^{2}$ \\ ${ }^{1}$ Faculty of Islamic Studies, Universitas Muhammadiyah Magelang, Indonesia \\ ${ }^{2}$ Faculty of Psychology and Humanities, Universitas Muhammadiyah Magelang, Indonesia \\ *Corresponding author. Email: minzaniaufa@ummgl.ac.id
}

\begin{abstract}
This research is an Action Research with the aim to determine the effect Student Teams Achievement Divisions (STAD) model on the learning achievement through five stages, such as planning, implementation, observation, measurement, and reflection. The results show that the level of learning achievement of 25 students at MI Muhammadiyah 1 Bumirejo is increased by $8 \%$ wherein cycle I was $76 \%$ and cycle II was $84 \%$. the average mastery of concepts also increased by $6.4 \%$ during the learning process wherein cycle I was $77.20 \%$ and cycle II was $83.60 \%$. Based on the results, there is an enhancement of STAD models on student learning achievement and the understanding the concepts of learning materials.
\end{abstract}

Keywords: STAD, student achievement, learning materials

\section{INTRODUCTION}

The teacher is a student learning facilitator who is expected to be able to overcome the difficulties experienced by students.[1] Teachers are required to be able to use a variety of learning models that are varied and able to present learning interestingly, the teacher is one of the main factors that affect student interest in learning other than the environment of the students themselves. So during the implementation of learning needed the right method so that students can be innovative, critical, and think logically [2]. Based on field study in class V at MI Muhammadiyah 1 Bumirejo, obtaining information that can support research. MI Muhammadiyah 1 Bumirejo is an MI that has quite a lot of students in Mungkid sub-district. Students at this MI come from several village areas with different backgrounds and knowledge. Class V students belong to the high-class group who have different backgrounds and knowledge. Class V students at MI Muhammadiyah 1 Bumirejo are less actively involved when the learning process is ongoing. Students are asked to listen when the teacher gives an explanation and occasionally students take notes from the teacher's explanation. This causes that students have not maximally developed the ability to behave, think, and have skills. Most fifth-grade students in the learning process are still passive, because students pay less attention to the teacher and participate in teaching and learning activities Conditions like those described above clearly have a negative impact on students. Based on data on student grades in Science subjects, it can be said that student achievement is relatively low. The average value is below the Minimum Mastery Criteria (KKM) value of 71. The low KKM value of student learning outcomes that is not satisfactory is not only caused by the student's condition, but is also influenced by various other things such as facilities, the environment, the teacher, or learning model applied.

The application of a learning model that is not right can lead to boredom, poorly understood, and monotonous so that students are less motivated to learn. The cooperative learning model is one of the learning models that demands the activeness of all students. Cooperative learning is learning that is intentionally designed to train students to listen to the opinions of others and summarize these opinions in written form. Cooperative learning models can improve student performance on academic assignments, excel in helping students understand concepts, and can help students foster critical thinking, cooperative skills, and abilities in helping peers among others [3].

Based on the definition of the learning model above it can be concluded that the learning model used by a teacher is very influential on the effectiveness and student learning outcomes, so a teacher must pay intense attention in the selection of learning models that will be implemented in order to achieve the expected learning goals

To solve the learning problem that needs to be done, among others, in the form of improving learning strategies, namely learning models that are expected to facilitate students in the process skills and Islamic characteristics so that more optimal results are achieved. One of the learning models developed by Slavin is the Student Teams Achievement Divisions (STAD) model. Explain that one type of cooperative learning that emphasizes interaction between students to help each other in mastering learning material [4]. This learning model teaches students to be placed in study groups consisting of 4-5 students who are a mix of students with different academic abilities so that in each group there are students who have low, medium and high achievement or variations in gender, racial and ethnic groups or other social groups.

STAD type of cooperative learning is one of the learning models that emphasizes team performance based on team recognition obtained from the sum of all individual progress scores of each team member [5]. The STAD type of cooperative learning model will influence student learning outcomes for Science because this learning emphasizes 
group work so that students are more receptive to the material delivered by the teacher.

Previous research findings indicate that the cooperative learning model helps students achieve their learning goals. Research conducted by Rina Pradiyanti (2013) found that STAD type cooperative models can increase student motivation [6]. As for the importance of the approach in this research, the theory will then be applied using various sources of reference. So, the identification of the problem is: how much results in the implementation of the Student Teams Achievement Divisions (STAD) type of learning model on student achievement and understanding the concept of learning materials for fifth grade students at MI Muhammadiyah 1 Bumirejo. In accordance with the formulation of the problem that has been stated previously, the main purpose of this study is:

a. To find out the results in applying the Student Teams Achievement Divisions (STAD) type of learning model to student achievement.

b. To find out the understanding of the concept of learning materials for fifth grade students at MI Muhammadiyah 1 Bumirejo.

\section{METHOD}

This research uses a quantitative approach to the Action Research method with an emphasis on applying the Student Teams Achievement Divisions (STAD) type of learning model to student learning achievement in science learning. To achieve the expected goals of influence in the application of the type learning model (STAD) in science learning, learning is carried out with Student Teams Achievement Divisions (STAD) with five stages 1) Planning, 2) Implementation, 3) Observation, 4) Measurement, and 5) Reflection, the five stages are carried out in 2 (two) times of the science learning cycle [7].

Data collection techniques used were observation, field notes, documentation, and tests. Meanwhile, data analysis techniques use quantitative descriptive. All data obtained are reviewed and reviewed through data categories, data validation and data interpretation, the step is to classify data and present data so that the data is clearly visible [8]. This research was conducted in the odd semester of the 2019/2020 school year at MI Muhammadiyah 1 Bumirejo. The subject of this research is class $\mathrm{V}$ with 25 students consisting of 13 male students and 12 female students. The research instrument used was a concept understanding test. Data analysis techniques used descriptive statistical analysis.

The measuring instrument used was a student achievement test that was used to determine learning outcomes. Student learning outcomes data obtained from test results in cycle 1 and cycle 2. Learning outcomes in the form of tests are entered into a table based on the average categorization of student learning outcomes [9], [10].

Table 1 Categorizing student learning achievement results

\begin{tabular}{|clc|}
\hline No & \multicolumn{1}{c|}{ Criteria } & Value \\
\hline 1 & Excellent & $90-100$ \\
2 & Very Good & $80-89$ \\
3 & Good & $70-79$ \\
4 & Fair & $60-69$ \\
5 & Poor & $\leq 59$ \\
\hline
\end{tabular}

This study describes the results of student science learning in terms of mastery aspects. The percentage of students' completeness can be searched by using the formula (Value $=($ Number of scores obtained $/$ maximum number of scores $)$ x $100 \%$. Class completeness criteria refer to the KKM that is equal to 71 .

Table 2 Student grades category

\begin{tabular}{|clc|}
\hline No & \multicolumn{1}{c|}{ Criteria } & Value \\
\hline 1 & Graduated & $71-100$ \\
\hline 2 & Failed & $0-70$ \\
\hline
\end{tabular}

The results of students' concept understanding tests are included in Table 3 based on their levels:

Table 3 Level of understanding of student concepts

\begin{tabular}{|clc|}
\hline Score & \multicolumn{1}{c|}{ Answer Type } & Level of concept understanding \\
\hline 3 & Correct and complete answer & Understand the Concepts \\
2 & Correct and incomplete answers & Understand some Concepts \\
1 & Wrong answer & Don't understand \\
\hline
\end{tabular}

\section{RESULTS AND DISCUSSION}

Muhammadiyah 1 Bumirejo learning model is presented in Table 4.

Student achievement data using the Student Teams Achievement Divisions (STAD) class V MI 
Table 4 Percentage of class v student learning outcomes in cycle I and cycle II through the application of the STAD learning model

\begin{tabular}{|cccccc|}
\hline Criteria & Value & $\begin{array}{c}\text { Total } \\
\text { students }\end{array}$ & $\begin{array}{c}\text { Cycle I } \\
\text { Percentage } \\
(\%)\end{array}$ & $\begin{array}{c}\text { Total } \\
\text { students }\end{array}$ & $\begin{array}{c}\text { Cycle II } \\
\text { Percentage } \\
(\%)\end{array}$ \\
\hline Excellent & $90-100$ & 2 & 8 & 10 & 40 \\
Very Good & $80-89$ & 8 & 32 & 6 & 24 \\
Good & $70-79$ & 11 & 44 & 8 & 32 \\
Fair & $60-69$ & 4 & 16 & 1 & 4 \\
Poor & $\leq 59$ & 0 & 0 & 0 & 0 \\
& & 25 & 100 & 25 & 100 \\
\hline
\end{tabular}

Data acquisition in Table 4 above, it can be analysed that students who are in the criteria of "excellent" in the first cycle were 2 students or $8 \%$ and in cycle II there were 10 students or $40 \%$, meaning that this criterion experienced a very high increase of $32 \%$. As for students who are in the criteria of "very good" in the first cycle a number of 8 students or $32 \%$ and in the second cycle a number of 6 students or $24 \%$ means that this criterion has decreased by $8 \%$. As for students who are in the criteria of "good" in the first cycle a number of 11 students or $44 \%$ and in the second cycle a number of 8 students or $32 \%$ means that on this

Table 5 Percentage of student mastery learning

\begin{tabular}{|lccccc|}
\hline \multicolumn{1}{|c}{ Criteria } & \multirow{2}{*}{ Value } & Total students & Cycle I & \multicolumn{2}{c|}{ Cycle II } \\
Percentage (\%)
\end{tabular}

Data acquisition in table 5 above, it can be analysed that students in the category of complete learning have increased from cycle I to cycle II. The number of students who completed the first cycle was 19 students or $76 \%$, while the students who completed the second cycle were 21 students or $84 \%$. From these data we can read that the implementation of the Student Teams Achievement Divisions (STAD) learning model has increased from cycle criterion has decreased by $12 \%$. Students who are in the criteria of "fair" in the first cycle of 4 students or $16 \%$ and in the second cycle of 1 student or $4 \%$ means that this criterion has decreased by $12 \%$.

The mastery of students learning science in MI Muhammadiyah 1 Bumirejo can be determined based on the KKM value, then it can be obtained through frequency distribution data and the percentage of completeness of learning science in cycle I and cycle II and can be seen in Table 5 below.

Table 6 Percentage test of understanding student concepts based on their grades

\begin{tabular}{|clccc|}
\hline No & Level of concept understanding & Cycle I & Cycle II & Average (\%) \\
\hline 1 & Understand the Concepts & 77.20 & 83.60 & 80.40 \\
2 & Understand some Concepts & 16.53 & 11.90 & 14.22 \\
3 & Don't understand & 6.25 & 4.50 & 5.37 \\
& Amount & 100 & 100 & 100 \\
\hline
\end{tabular}

The results of the analysis in table 6 that the "understanding of the concept" of student learning materials in the first cycle amounted to $77.20 \%$ and in the second cycle amounted to $83.60 \%$ meaning that students' understanding of concepts in science subjects increased by $6.40 \%$. At the level of "understanding some concepts" student learning materials in the first cycle amounted to $16.53 \%$ and at the second cycle amounted to $11.90 \%$ meaning that the students' understanding of concepts in science subjects decreased by $4.63 \%$. And finally, at the level of "not understanding" student learning materials in the first cycle amounted to $6.25 \%$ and the second cycle amounted to
I to cycle II, which is $8 \%$. In table 5 it can be analyzed that in the category of incomplete student learning in cycle I numbered 6 students or $24 \%$ and in cycle II students who did not complete a number of 4 students or $16 \%$. From these data we can read that students' learning incomplete in cycle I and cycle II decreased by $8 \%$. The percentage data from the increase in students' understanding of learning materials tests can be seen in Table 6 . 
[2] R. S. Ernawita, "Penerapan Model Pembelajaran Kooperatif Tipe Student Teams Achievement Division Terhadap Motivasi Belajar Peserta Didik Di SMAN 8 Banda Aceh,” J. Pendidik. Sains Indones., vol. 06, no. 01, pp. 9-16, 2018.

[3] F. N. Khumaeroh, D. T. Sunarya, and R. L. Panjaitan, "Penerapan Model Pembelajaran Kooperatif Tipe Student Team Achievement Division ( Stad ) Dengan Menggunakan Metode Generating Interaction Between Schemata and Text ( Gist ) Untuk Meningkatkan Kemampuan Membandingkan Isi Dua Teks,” J. Pena Ilm., vol. 1, 2016.

[4] F. T. Itsnaini and Suryanti, "Efektivitas Model Pembelajaran Kooperatif STAD (Student Team Achievement Division) Pada Hasil Belajar IPA Siswa dalam Materi pada Tema 2 Subtema 2 Pembelajaran 1 Kelas IV di SDN Gading VIII/ 554 Surabaya," J. PGSD, vol. 6, no. 10, pp. 1876-1885, 2018.

[5] Rochmatin and G. Gunansyah, "Penerapan Model Pembelajaran Kooperatif Tipe STAD Meningkatkan Hasil Belajar Siswa dalam Pembelajaran IPS Kelas IV," J. PGSD, vol. 02, no. 03, 2014.

[6] S. Rina Pradiyanti, Edy Cahyono, "Pembelajaran Laju Reaksi Model Kooperatif Tipe STAD untuk Meningkatkan Efektivitas Belajar Siswa,” J. Innov. Sci. Educ., vol. 2, no. 1, 2013.

[7] S. Dewita, "Peningkatan pembelajaran IPS dengan menggunakan model kooperatif tipe Student Team Achievement Division ( STAD ) di kelas V SDN 36 Rangeh Kecamatan Lengayang Kabupaten Pesisir Selatan,” J. Penelit. Guru Indones., vol. 3, no. 1, pp. $15-26,2018$.

[8] K. A. Esminarto, Sukowati, Nur Suryowati, "Implementasi Model STAD dalam Meningkatkan Hasil Belajar Siwa,” BRILIANT J. Ris. dan Konseptua, vol. 1, no. 1, pp. 16-23, 2016.

[9] I. Wardana, T. Banggali, and H. Husain, "Penerapan Model Pembelajaran Kooperatif Tipe Student Team Achievement Division (STAD) untuk Meningkatan Hasil Belajar Siswa Kelas XI IPA Avogadro SMA Negeri 2 Pangkajene (Studi pada Materi Asam Basa)," J. Chem., vol. 18, no. 1, pp. 76-84, 2017.

[10] S. Arikunto, Dasar-dasar Evaluasi Pendidikan. Jakarta: Bumi Aksara, 2008.
[1] M. U. Shabir, "Kedudukan Guru Sebagai Pendidik: (Tugas dan Tanggung Jawab, Hak dan Kewajiban, dan Kompetensi Guru)," Auladuna, vol. 2, no. 2, pp. 221$232,2015$. 